\title{
Social networking sites and fashion e-purchasing process
}

\author{
Ghaith M. Al-Abdallah \\ Abdallah Q. Bataineh \\ Department of Marketing, Faculty of Business \\ Applied Science Private University, Jordan
}

\section{Keywords}

Social networking sites, e-word of mouth, e-reference groups, e-purchasing, fashion sector.

\begin{abstract}
The Internet and social networking sites have provided many benefits to its users, because of its ability to connect large number of users all over the world; it is used as a marketing tool to promote different goods and services, including fashion. This study aimed to reveal the impact of social networking sites and their applications, e-word of mouth and e-reference groups in particular, on the epurchasing process of fashion products. This process undergoes five consecutive stages (need recognition, information search, alternatives' evaluation, e-purchasing, post-purchasing evaluation). In order to achieve the objectives of this study, analytical descriptive method was used and quantitative approach utilizing survey strategy was applied to test the three main hypotheses developed based on the literature review. Questionnaire was developed based on the previous studies and electronically distributed to a connivance sample of 601 online fashion buyers who have active Facebook accounts. 427 filtered and screened questionnaires were analyzed using SPSS. Descriptive analyses and regression analyses were performed to describe and test the hypotheses. The study found that the ereference groups have slightly stronger impact on e-purchasing process in the fashion sector compared to e-word of mouth. The study recommended that e-stores should pay attention to consumers' experience to ensure positive feedback on social networking sites, and to the quality of information offered on fashion products. Recommendations for future research are provided.
\end{abstract}

Corresponding author: Ghaith M. Al Abdallah

Email addresses for corresponding author: ghaith.abdallah@yahoo.com

First submission received: $23^{\text {rd }}$ March 2018

Revised submission received: $26^{\text {th }}$ May 2018

Accepted: $24^{\text {th }}$ July 2018

\subsection{Research Background}

By the end of 2016, the number of Internet users in Jordan exceeded 3.4 million who use different internet-based service technologies (Internetlivestats, 2016). This number form around $45.7 \%$ from the total population of the country (Internetlivestats, 2016). The internet advantages in improving marketing process due to its low cost, speed, flexibility and effectiveness in contacting the targeted consumers encouraged the companies to connect their traditional promotional methods with the online ones, creating their own model of e-marketing. However, and despite the remarkable penetration rate of internet in the Arab countries in general and Jordan in particular, the level of internet usage for "e-purchase" in the developed countries is significantly higher than the level found in the Arab countries. For instance, the number of online buyers in Jordan was less than 1.6 million in 2015, not to mention that most purchases were for really small values. The fashion sector is one of the most important and most active sectors for ecommerce worldwide. However, only 352 Thousand of online buyers in Jordan bought fashion products in 2015, forming around 22\% of the total number of online buyers in Jordan (Befort, 2015). Such numbers raise serious questions about the reasons behind such discrepancies and what affect the decision-making process and the e-purchasing process.

Marketing has always been a social experience; therefore, the social networks help customers to interact with each other, even if they do not know the others in person, creating virtual connections and relationships (Pookulangaran et al., 2011). According to the Arab Social Media Report (2015), users' perceptions across the Arab world showed that around 44\% trust social networking sites, the decision to 
buy and discuss personal experiences can affect the consumers' purchasing habits. The individual tends to benefit from the experiences of others about a specific product and thus influence their e-purchase decisions. In addition, around 39\% of Internet users browse social networking sites to search for published information by other users about the products they are interested in (AIMIA, 2013). Therefore, it became necessary to investigate the scientific impact of social networking sites on consumers e-purchasing decision especially in the fashion sector as social networking sites are consider as the new platform for fashion "moda" and trends, with the emerging of what so called "Fashionistas" attracting different segments of consumers to such pages.

\subsection{Literature Review}

\subsection{The Concept of Social Networking Sites}

According to Curran et al. (2014) Social networking sites have witnessed significant developments since the 1990s, where internet has become the social communication medium most people used and as part of their daily routine, this contributed to the radical transformations of human lives. Social networking can be interpreted as the available sites on the internet that allow users to communicate, dialogue and exchange ideas through their applications, which range from chat rooms, photo albums, to video share and personal posts. The most prominent examples of the social networking that exist today are Facebook, Instagram, Twitter, YouTube, LinkedIn and Google plus. They all involve the creation of a set of e-social identities that individuals or even institutions establish to improve personal and professional relationships (Debsi \& Tahat, 2013). The number of social networking sites is estimated in millions and increases on daily basis.

Facebook (king of social media) is the most popular site internationally and locally among the various social networking sites (ARABSIMS, 2015). At the end of 2015, the recorded statistics indicated that the active Facebook accounts in Jordan estimated at 4,100,000. However, it should be clear that some users have more than one Facebook account, some for personal use and some for business and marketing purposes only.

\subsection{Electronic Word of Mouth}

Sowaydan (2011) defines the word of mouth as positive or negative feedback transferred to another consumer by a consumer as a result of a received product and service. The e-word of mouth has the same features of ads, but its quality is determined by the product information highlighted in the feedback, the way in which it was written and whether it has added useful information or not (Xiaofen \& Yiling, 2009). The positive feedback from a comment, likes or sharing is important in reducing ambiguity about the displayed product and the degree of uncertainty that accompanies the purchasing decision (Gremler et al., 2001). The consumers are influenced by negative e-word of mouth more than the positive ones (Shahana \& Dawn, 2007). Consumers in general, and in the fashion industry, usually ask others for help and advice on products to buy (Mauri \& Minnazi, 2013). The importance of the e-word of mouth is transferred to all purchasing decision stages, according to Cheung and Lee (2012) the explosive growth of the Internet significantly increased the importance of e-word of mouth delivered to a large number of people around the world, which also made it possible for consumers to discuss and exchange opinions and reviews.

\subsection{Electronic Reference Groups}

Reference groups can be defined as group of individuals that affect the personal behavior of people and direct them to certain paths (Obidat, 2004). According to Bakri (2006) reference groups are group of individuals that affect directly and indirectly the consumption attitudes and behaviors of people. Reference groups are what individuals refer to as standards and norms used to evaluate their own behavior, which can be classified into two main categories as follow:

\subsubsection{Primary Groups}

Primary groups can be described as informal relatively small social groups that share intimate, personal, long lasting relationships among its members. Primary groups shared concern for one another as well and affect the attitudes and behaviors of its members. A good example of primary groups is nuclear family and close friends (Andersen et al., 2010; Bakri, 2006). 


\subsubsection{Secondary Groups}

Secondary groups can be defined as formal (and semi-formal) groups that affect the behavior of people. The members of secondary groups normally interact on a less personal level compared to the primary ones. Another difference between secondary and primary groups is the fact that normally individuals willingly choose to be part of the secondary groups. A good example of secondary groups is friends, neighborhoods, acquaintances, sports teams, professional colleagues, and official communities (Andersen et al., 2010; Bakri, 2006).

\subsection{Stages of Consumer Decision Making Process}

Commonly, there are five stages in the process of purchasing, whether traditional or electronic. The stages can be summarized as follows:

Need recognizing is the first stage, where the consumer feels there is a shortage or desire to cover something missing through the action of purchase (Kotler \& Armstrong, 2012). The second stage is the information search, where the consumer starts up searching for all the information related to the available alternatives that might fulfill his need. The sources of information that the consumer depends on are either internal or external; mostly the family, friends, study and work colleagues in addition to the personal experience. The consumer is often interested in collecting information about the quality of the products, prices and best-selling places, in addition to the available methods of payment. The duration of this stage varies according to the characteristics and personality traits of the consumer (Kotler, 2011). The third stage will be the alternatives evaluation stage, where the consumer starts an assessment of all the available alternatives that he managed to obtain in the previous stage. The evaluation normally focuses on the quality and specifications of the goods and/or services being assessed, however, consumers depend on selection criteria that they have developed during the previous stages, the assessments aim to differentiation between the available options, this is very likely to be affected by the demographic, psychological characteristics and consumers purchasing capabilities (Hisham \& Abuhmeida, 2007).

The next stage is the purchasing stage, which is one of the most important stages of the purchasing process because it is implicitly associated with all the previous stages. It is considered as a result of the differentiation and evaluation process of all available alternatives. The purchasing stage is normally a natural result of a number of partial decisions related to the product, which can be acquired from a specific place, at a specific time and mechanism, and according to the certain price (Hisham \& Abu Humida, 2007). In order to consider the product purchasing stage an electronic one the purchase should take place in the internet (online) even of some of some of the other stages of the purchasing process did not. It should be clear that all marketing practices and activities affect in one way or another purchase stage (Abdul Hamid, 2010).

Post-purchase evaluation is the last stage of the process, once the consumer has made the purchase, he evaluates his purchasing decision in terms of to which degree did the product he got satisfy his needs and wants (wishes and desires) and to which level the product performance matches his/her expectations. The evaluation of the product is often classified as positive and negative (Hisham \& Abu Humida, 2007). If this stage is not carried out successfully, the consumer will remain in constant uncertainty, thus not returning to buy the same product again, and will return to the initial stages of making a purchasing decision for the same product in the future (Sumaidai \& Yousef, 2007).

\subsection{Conceptual Model}

The conceptual model was built based on previous studies and literature review as presented in figure (1) below.

Independent Variables

Dependent Variables

\begin{tabular}{|l|l|}
\hline \multicolumn{1}{|c|}{ Social Media Networks } & \multicolumn{1}{c|}{$\begin{array}{c}\text { E- Purchasing Process } \\
\text { - Need Recognition of the Product } \\
\text { - E-word of Mouth } \\
\text { - E-reference groups }\end{array}$} \\
- Information Search \\
- Alternatives Evaluation \\
Figure (1): The Research Model
\end{tabular}

Figure (1): The Research Model 
Source: Developed by the researcher based on the literature review and previous studies (Luís \& Sebra, 2013; Daugherty, 2009; Tayeh, 2007).

\subsection{Research Methodology}

Since this study is describing an existing phenomenon, the research utilized descriptive analytical methodology to achieve the aims of this study. Since this research is based developing hypotheses based on literature review and then test theses hypotheses in the targeted population, a deductive approach was used for this research. Quantitative approach was used to collect the research data through survey strategy that utilized questionnaire as the research instrument. The research instrument was developed based on the literature review and the results of the pilot study, in which a panel of expertise in the field of study was approached and their comments on the research instrument were addressed properly.

The questionnaire consisted of three parts plus the cover letter, the first part of the questionnaire collected data on the independent variables (social networking sites) and contained 11 statements, the second part collected data on the dependent variable (the five stages of e-purchasing process) and contained 38 statements, the third part collected the demographics of the sample and contained 8 questions. The first two parts of the questionnaire used five points Likert scale ranging from strongly agree to strongly disagree.

\subsection{Population and Sample}

The population of the study consisted of all consumers who purchase fashion products electronically; the number is estimated around 352,000 consumers that equal $22 \%$ of about 1.6 million ebuyers in Jordan (Befort, 2015). The main active fashion e-stores in Jordan were approached to identify the population of the study as accurate as possible based on their customers' database.

A connivance sample was found to be the most appropriate to the nature of the study, the sample was drafted from the lists obtained from e-stores and designated websites, mainly Markavip and Souq. The sample unit must have at least one active account on Facebook to be considered within the sample. Accordingly, 601 users have been identified to be the sample of this study with a margin error of $4 \%$.

The questionnaire was distributed electronically via SurveyMonkey, where a link was created on the site and sent to the active Facebook accounts of the selected sample and a follow up message was sent to all participants few days later. Out of 601,436 questionnaires were retrieved with a response rate of $72.5 \%$, and after the filtration process 9 questionnaires were excluded. Accordingly, 427 screened and filtered questionnaires were analyzed utilizing SPSS.

\subsection{Research Reliability}

The reliability of the instrument was measured through the test of Cronbach Alpha coefficient to confirm the consistency of the scale and to check the degree of stability. Table (1) shows the results of the instrument reliability.

\begin{tabular}{|l|l|l|l|}
\hline No. & Variables & \# of Statements & Cronbach Alpha Value \\
\hline 1 & E-Word of Mouth & 4 & 0.803 \\
\hline 2 & E-Reference Groups & 7 & 0.834 \\
\hline & $\begin{array}{l}\text { The Total of Social Networking } \\
\text { sites }\end{array}$ & 11 & 0.878 \\
\hline 3 & Need Recognition & 7 & 0.903 \\
\hline 4 & Information Search & 7 & 0.853 \\
\hline 5 & Alternatives Evaluation & 7 & 0.840 \\
\hline 6 & E-Purchasing Evaluation and & 6 & 0.817 \\
\hline 7 & $\begin{array}{l}\text { Post-Purchasing Evack } \\
\text { Feedback }\end{array}$ & 0.879 \\
\hline$*$ & E-Purchasing Process & 34 & 0.932 \\
\hline & The Total Questionnaire & 45 & 0.964 \\
\hline
\end{tabular}

Table (1): Cronbach Alpha ( $\alpha$ ) Approach for Main Constructs and Dimensions

Table (1) represented the reliability values of all study variables. It was clear that all the variables had high internal consistency values. All the values were suitable and adequate for the purposes of the 
study and indicated appropriate reliability values, all of which were greater than $(0.60)$ the cutoff point according to the Cohen standard, which indicate that the instrument carries a high degree of reliability (Creswell, 2005).

\subsection{Data Analysis}

Both descriptive statics and regression analyses were performed to describe the data and test the hypotheses.

\subsection{Sample Characteristics}

The study included eight demographic variables (Gender, Age, Educational level, Job Title, Income Level (Monthly), Internet usage in a normal day (Hours), Social Networks share of internet usage (Daily), and Organize the following social networking sites according to the most used one by you (daily)). Table (2) represented the sample characteristics of the study.

\begin{tabular}{|c|c|c|c|}
\hline Variables & Intervals & Number & Percentage \\
\hline \multirow[t]{3}{*}{ Gender } & Male & 124 & 29.0 \\
\hline & Female & 303 & 71.0 \\
\hline & Total & 427 & 100.0 \\
\hline \multirow[t]{5}{*}{ Age } & Below 22 years & 112 & 26.2 \\
\hline & 22 to Less than 30 years & 161 & 37.9 \\
\hline & 30 to Less than 40 & 128 & 29.9 \\
\hline & 40 and more & 26 & 6.1 \\
\hline & Total & 427 & 100.0 \\
\hline \multirow[t]{5}{*}{ Education Level } & General Certificate and Less & 20 & 4.7 \\
\hline & Diploma & 54 & 12.6 \\
\hline & Bachelor & 295 & 69.2 \\
\hline & Postgraduate & 58 & 13.6 \\
\hline & Total & 427 & 100.0 \\
\hline \multirow[t]{6}{*}{ Current Position (Job) } & Students & 100 & 23.4 \\
\hline & Governmental Sector Employee & 82 & 19.2 \\
\hline & Private Sector Employee & 129 & 30.4 \\
\hline & Free & 66 & 15.4 \\
\hline & Other & 50 & 11.7 \\
\hline & Total & 427 & 100.0 \\
\hline \multirow[t]{6}{*}{ Income Level Per Month in Jordanian Dinar } & 300 or Less & 34 & 7.9 \\
\hline & 300 to Less Than 800 & 128 & 29.9 \\
\hline & 800 to Less Than 1400 & 141 & 33.2 \\
\hline & 1400 to Less Than 2200 & 76 & 17.8 \\
\hline & 2200 or More & 48 & 11.2 \\
\hline & Total & 427 & 100.0 \\
\hline \multirow[t]{6}{*}{ Daily Internet Usage (Hours) } & Less Than An hour & 62 & 14.5 \\
\hline & 1 to Less Than 2 & 159 & 37.4 \\
\hline & 2 to Less Than 4 & 148 & 34.6 \\
\hline & 4 to Less Than 6 & 40 & 9.3 \\
\hline & More Than 6 & 18 & 4.2 \\
\hline & Total & 427 & \\
\hline Social Networking Sites Share (Hours) & Less Than An hour & 70 & 16.4 \\
\hline
\end{tabular}

www.jbrmr.com A Journal of the Academy of Business and Retail Management (ABRM) 


\begin{tabular}{|l|l|l|l|}
\hline & 1 to Less Than 2 & 163 & 38.2 \\
\hline & 2 to Less Than 4 & 140 & 32.8 \\
\hline & 4 to Less Than 6 & 38 & 8.9 \\
\hline & More Than 6 & 16 & 3.7 \\
\hline & Total & 427 & 100.0 \\
\hline
\end{tabular}

Table (2): Describing the Sample's Personal and Demographic Variables

\subsection{Hypotheses Testing}

Simple and multiple linear regression were applied to examine the impact of social networking sites on e-purchasing decision process through three main hypotheses.

In order to do this Skewness and VIF needed to be established first, the results are presented in table 3 below.

\begin{tabular}{|c|c|c|c|c|}
\hline No. & Variables & Skewness & VIF & Tolerance \\
\hline 1 & E-Word of Mouth & -0.935 & 1.938 & 0.516 \\
\hline \multirow[t]{2}{*}{2} & E-Reference Groups & -0.877 & 1.938 & 0.516 \\
\hline & The Total of Social Networking sites & -1.108 & & \\
\hline 3 & Need Recognition & -1.501 & & \\
\hline 4 & Information Search & -1.568 & & \\
\hline 5 & Alternatives Evaluation & -0.787 & & \\
\hline 6 & E-Purchasing & -0.681 & & \\
\hline \multirow[t]{2}{*}{7} & Post-Purchasing Evaluation & -0.428 & & \\
\hline & E-Purchasing Process & -1.322 & & \\
\hline
\end{tabular}

Table (3) Skewness, Co Linearity Diagnosis and Tolerance

Table (3) indicates the results of skewness as one of the most basic assumption to be checked prior to applying linear regression. The skewness values ranged between $(-0.428)$ for post-purchasing evaluation and (-1.568) for information search. These values suggest that the data for study variables exhibit approximately normal as they range between $( \pm 3)$ which most studies accept to express normal distribution behavior for the variables data. Co linearity is the linear correlation between the two given predictor variables. Linear regression assumes small amounts of correlation among the predictors less than 5 (Maddala, 1992), the maximum value of co linearity obtained is (1.938). This value suggests a very low co linearity concluding that a basic condition to applying linear regression has been met.

Based on table (3) above, the regression tests can be applied, and the results are presented below: HO1: There is a significant impact of social networking sites on e-purchasing process at $a \leq 0.05$.

\begin{tabular}{|c|c|c|c|c|c|c|c|c|}
\hline Independent Variables & $\mathrm{r}$ & $\mathrm{R}^{2}$ & $\mathrm{f}$ & Sig $\mathrm{f}$ & $\beta 0$ & $\beta$ Coefficient & $\mathrm{t}$ & Sig $\mathrm{t}$ \\
\hline E-Word of Mouth & \multirow{2}{*}{0.926} & \multirow[t]{2}{*}{0.858} & \multirow{2}{*}{637.0} & \multirow[t]{2}{*}{0.000} & \multirow{2}{*}{0.876} & 0.342 & 12.00 & 0.000 \\
\hline E-Reference Groups & & & & & & 0.400 & 15.79 & 0.000 \\
\hline
\end{tabular}

Table (4) Multi Linear Regression for Testing the HO1

Table (4) indicates the result of testing the impact of social networking sites on e-purchasing process. The $\mathrm{f}$ value (637) is significant because the related $\mathrm{p}$ value $(0.000)$ is statistically significant $(<$ $0.05)$. The beta coefficient reflects the impact value in the independent variable. The results show that the e-word of mouth (0.342) and e-reference group (0.400) significantly contribute to the dependent variable as the probability of $t$ statistics was $<0.05$. The $t$ statistics tests the linearity importance of the beta coefficient obtained for the independent variable. The value of R2 expresses the prediction strength of the dependent variable using the independent variable; R2 value is $(85.8 \%)$ which is a high percentage. This value also can be viewed as the variation percentage in the dependent variable that can be accounted for (i.e explained by) the independent variable.

As a result, the alternative hypothesis is accepted. 
HO2: There is a significant impact of e-reference groups on e-purchasing process at $a \leq 0.05$.

\begin{tabular}{|l|l|l|l|l|l|l|l|l|}
\hline $\begin{array}{l}\text { Independent } \\
\text { Variables }\end{array}$ & $\mathrm{r}$ & $\mathrm{R}^{2}$ & $\mathrm{f}$ & $\operatorname{Sig} \mathrm{f}$ & $\beta 0$ & $\beta$ Coefficient & $\mathrm{t}$ & Sig t \\
\hline $\begin{array}{l}\text { E-Reference } \\
\text { Groups }\end{array}$ & 0.872 & 0.761 & 674.0 & 0.000 & 1.373 & 0.612 & 25.97 & 0.000 \\
\hline
\end{tabular}

Table (5) Simple Linear Regression for Testing the HO2

As presented in table (5), the $\mathrm{f}$ value (674) is significant because the related $\mathrm{p}$ value $(0.000)$ is statistically significant $(<0.05)$. The beta coefficient reflects the impact value in the independent variable. The beta coefficient value is $(0.612)$ and significantly contributes to the dependent variable as the probability of $t$ statistics is $(0.000)<0.05$. The $t$ statistics tests the linearity importance of the beta coefficient obtained for the independent variable.

The value of $\mathrm{R} 2$ expresses the prediction strength of the dependent variable using the independent variable, $\mathrm{R} 2$ value is $(76.1 \%)$ and this value also can be viewed as the variation percentage in the dependent variable that can be accounted for (i.e. explained by) the independent variable.

As a result, the alternative hypothesis is accepted.

HO2.1: There is a significant impact of e-reference groups on need recognition at $\alpha \leq 0.05$.

\begin{tabular}{|l|l|l|l|l|l|l|l|l|}
\hline Independent Variables & $\mathrm{r}$ & $\mathrm{R}^{2}$ & $\mathrm{f}$ & $\operatorname{Sig} \mathrm{f}$ & $\beta 0$ & $\beta$ Coefficient & $\mathrm{t}$ & $\operatorname{Sig~t}$ \\
\hline E-Reference Groups & 0.791 & 0.625 & 353.7 & 0.000 & 0.919 & 0.779 & 18.8 & 0.000 \\
& & & & & & & \\
\hline
\end{tabular}

Table (6) Simple Linear Regression for Testing the HO2.1

As presented in table (6), the $\mathrm{f}$ value (353.7) is significant because the related $\mathrm{p}$ value $(0.000)$ is statistically significant $(<0.05)$. The beta coefficient reflects the impact value in the independent variable. The beta coefficient value is (0.779) and significantly contributes to the dependent variable as the probability of $\mathrm{t}$ statistics is $(0.000)<0.05$. The $\mathrm{t}$ statistics tests the linearity importance of the beta coefficient obtained for the independent variable. The value of R2 expresses the prediction strength of the dependent variable using the independent variable, $\mathrm{R} 2$ value is $(62.5 \%)$ and this value also can be viewed as the variation percentage in the dependent variable that can be accounted for (i.e. explained by) the independent variable.

As a result, the alternative hypothesis is accepted.

HO2.2: There is a significant impact of e-reference group on information search $a \leq 0.05$.

\begin{tabular}{|l|l|l|l|l|l|l|l|l|}
\hline $\begin{array}{l}\text { Independent } \\
\text { Variables }\end{array}$ & $\mathrm{r}$ & $\mathrm{R}^{2}$ & $\mathrm{f}$ & $\operatorname{Sig} \mathrm{f}$ & $\beta 0$ & $\beta$ Coefficient & $\mathrm{t}$ & Sig t \\
\hline E-Reference Groups & 0.838 & 0.703 & 501.5 & 0.000 & 0.997 & 0.748 & 22.39 & 0.000 \\
& & & & & & & \\
\hline
\end{tabular}

Table (7) Simple Linear Regression for Testing the HO2.2

As presented in table (7), the $f$ value (501.) is significant because the related $p$ value $(0.000)$ is statistically significant $(<0.05)$. The beta coefficient reflects the impact value in the independent variable. The beta coefficient value is (0.748) and significantly contributes to the dependent variable as the probability of $\mathrm{t}$ statistics is $(0.000)<0.05$. The $\mathrm{t}$ statistics tests the linearity importance of the beta coefficient obtained for the independent variable. The value of R2 expresses the prediction strength of the dependent variable using the independent variable, $\mathrm{R} 2$ value is $(70.3 \%)$ and this value also can be viewed as the variation percentage in the dependent variable that can be accounted for (i.e. explained by) the independent variable.

As a result, the alternative hypothesis is accepted.

HO2.3: There a significant impact of e-reference groups on alternatives evaluation $\alpha \leq 0.05$.

www.jbrmr.com A Journal of the Academy of Business and Retail Management (ABRM) 


\begin{tabular}{|l|l|l|l|l|l|l|l|l|}
\hline $\begin{array}{l}\text { Independent } \\
\text { Variables }\end{array}$ & $\mathrm{r}$ & $\mathrm{R} 2$ & $\mathrm{f}$ & Sig f & $\beta 0$ & $\beta$ Coefficient & $\mathrm{t}$ & Sig t \\
\hline $\begin{array}{l}\text { E-Reference } \\
\text { Groups }\end{array}$ & 0.781 & 0.611 & 332.3 & 0.000 & 1.070 & 0.714 & 28.18 & 0.000 \\
\hline
\end{tabular}

Table (8) Simple Linear Regression for Testing the HO2.3

As presented in table (8), the $f$ value (332.3) is significant because the related $p$ value $(0.000)$ is statistically significant $(<0.05)$. The beta coefficient reflects the impact value in the independent variable. The beta coefficient value is $(0.714)$ and significantly contributes to the dependent variable as the probability of $\mathrm{t}$ statistics is $(0.000)<0.05$. The $\mathrm{t}$ statistics tests the linearity importance of the beta coefficient obtained for the independent variable. The value of R2 expresses the prediction strength of the dependent variable using the independent variable, $\mathrm{R} 2$ value is $(61.1 \%)$ and this value also can be viewed as the variation percentage in the dependent variable that can be accounted for (i.e explained by) the independent variable.

As a result, the alternative hypothesis is accepted.

HO2.4: There is a significant impact of e-reference group on e-purchasing at $a \leq 0.05$.

\begin{tabular}{|l|l|l|l|l|l|l|l|l|}
\hline $\begin{array}{l}\text { Independent } \\
\text { Variables }\end{array}$ & $\mathrm{r}$ & $\mathrm{R}^{2}$ & $\mathrm{f}$ & Sig f & $\beta 0$ & $\beta$ Coefficient & $\mathrm{t}$ & Sig t \\
\hline E-reference Groups & 0.727 & 0.528 & 237.3 & $0.000^{*}$ & 1.314 & 0.664 & 15.40 & 0.000 \\
& & & & & & & & \\
\hline
\end{tabular}

Table (9) Simple Linear Regression for Testing the HO2.4

As presented in table (9), the $\mathrm{f}$ value (237.3) is significant because the related $\mathrm{p}$ value $(0.000)$ is statistically significant $(<0.05)$. The beta coefficient reflects the impact value in the independent variable. The beta coefficient value is (0.664) and significantly contributes to the dependent variable as the probability of $\mathrm{t}$ statistics is $(0.000)<0.05$. The $\mathrm{t}$ statistics tests the linearity importance of the beta coefficient obtained for the independent variable. The value of R2 expresses the prediction strength of the dependent variable using the independent variable, $\mathrm{R} 2$ value is $(52.8 \%)$ and this value also can be viewed as the variation percentage in the dependent variable that can be accounted for (i.e explained by) the independent variable.

As a result, the alternative hypothesis is accepted.

HO2.5: There a significant impact of e-reference group on post-purchasing evaluation at $\alpha \leq 0.05$.

\begin{tabular}{|l|l|l|l|l|l|l|l|l|}
\hline Independent Variables & $\mathrm{r}$ & $\mathrm{R}^{2}$ & $\mathrm{f}$ & $\operatorname{Sig} \mathrm{f}$ & $\beta 0$ & $\beta$ Coefficient & $\mathrm{t}$ & $\operatorname{Sig} \mathrm{t}$ \\
\hline E-reference Groups & 0.288 & 0.083 & 19.10 & 0.000 & 2.563 & 0.153 & 4.37 & 0.000 \\
& & & & & & & & \\
\hline
\end{tabular}

Table (10) Simple Linear Regression for Testing the HO2.5

As presented in table (10), the $\mathrm{f}$ value (19.1) is significant because the related $\mathrm{p}$ value $(0.000)$ is statistically significant $(<0.05)$. The beta coefficient reflects the impact value in the independent variable. The beta coefficient value is $(0.153)$ and significantly contributes to the dependent variable as the probability of $t$ statistics is $(0.000)<0.05$. The $t$ statistics tests the linearity importance of the beta coefficient obtained for the independent variable. The value of R2 expresses the prediction strength of the dependent variable using the independent variable, R2 value is $(8.3 \%)$ which is relatively a low percentage, this value also can be viewed as the variation percentage in the dependent variable that can be accounted for (i.e. explained by) the independent variable.

As a result, the alternative hypothesis is accepted.

HO3: There is a significant impact of e-word of mouth on e-purchasing process at $a \leq 0.05$.

www.jbrmr.com A Journal of the Academy of Business and Retail Management (ABRM) 


\begin{tabular}{|l|l|l|l|l|l|l|l|l|}
\hline $\begin{array}{l}\text { Independent } \\
\text { Variables }\end{array}$ & $\mathrm{r}$ & $\mathrm{R}^{2}$ & $\mathrm{f}$ & $\operatorname{Sig} \mathrm{f}$ & $\beta 0$ & $\beta$ Coefficient & $\mathrm{t}$ & Sig t \\
\hline E-Word of Mouth & 0.831 & 0.690 & 471.7 & 0.000 & 1.228 & 0.656 & 21.71 & 0.000 \\
& & & & & & & \\
\hline
\end{tabular}

Table (11) Simple Linear Regression for Testing the HO3

As presented in table (11), the $f$ value (471.7) is significant because the related $p$ value $(0.000)$ is statistically significant $(<0.05)$. The beta coefficient reflects the impact value in the independent variable. The beta coefficient value is (0.656) and significantly contributes to the dependent variable as the probability of $t$ statistics is $(0.000)<0.05$. The $t$ statistics tests the linearity importance of the beta coefficient obtained for the independent variable. The value of R2 expresses the prediction strength of the dependent variable using the independent variable, R2 value is $(69 \%)$ and this value also can be viewed as the variation percentage in the dependent variable that can be accounted for (i.e. explained by) the independent variable.

As a result, the alternative hypothesis is accepted.

HO3.1: There is a significant impact of e-word of mouth on need recognition for a product at $\alpha \leq 0.05$.

\begin{tabular}{|l|l|l|l|l|l|l|l|l|}
\hline $\begin{array}{l}\text { Independent } \\
\text { Variables }\end{array}$ & $\mathrm{r}$ & $\mathrm{R}^{2}$ & $\mathrm{f}$ & $\operatorname{Sig} \mathrm{f}$ & $\beta 0$ & $\beta$ Coefficient & $\mathrm{t}$ & Sig $\mathrm{t}$ \\
\hline E-Word of Mouth & 0.670 & 0.449 & 172.7 & 0.000 & 172.73 & 0.743 & 13.14 & 0.000 \\
\hline
\end{tabular}

Table (12) Simple Linear Regression for Testing the HO3.1

As presented in table (12), the $f$ value (172.7) is significant because the related $p$ value $(0.000)$ is statistically significant $(<0.05)$. The beta coefficient reflects the impact value in the independent variable. The beta coefficient value is (0.743) and significantly contributes to the dependent variable as the probability of $\mathrm{t}$ statistics is $(0.000)<0.05$. The $\mathrm{t}$ statistics tests the linearity importance of the beta coefficient obtained for the independent variable. The value of R2 expresses the prediction strength of the dependent variable using the independent variable, $\mathrm{R} 2$ value is $(44.9 \%)$ and this value also can be viewed as the variation percentage in the dependent variable that can be accounted for (i.e explained by) the independent variable.

As a result, the alternative hypothesis is accepted.

HO3.2: There is a significant impact of e-word of mouth on information search at $a \leq 0.05$.

\begin{tabular}{|l|l|l|l|l|l|l|l|l|}
\hline $\begin{array}{l}\text { Independent } \\
\text { Variables }\end{array}$ & $\mathrm{r}$ & $\mathrm{R}^{2}$ & $\mathrm{f}$ & $\operatorname{Sig} \mathrm{f}$ & $\beta 0$ & $\beta$ Coefficient & $\mathrm{t}$ & Sig t \\
\hline E-word of Mouth & 0.727 & 0.528 & 237.3 & 0.000 & 1.098 & 0.730 & 15.40 & 0.000 \\
\hline
\end{tabular}

Table (13) Simple Linear Regression for Testing the HO3.2

As presented in table (13), the $f$ value (237.3) is significant because the related $p$ value $(0.000)$ is statistically significant $(<0.05)$. The beta coefficient reflects the impact value in the independent variable. The beta coefficient value is (0.730) and significantly contributes to the dependent variable as the probability of $\mathrm{t}$ statistics is $(0.000)<0.05$. The $\mathrm{t}$ statistics tests the linearity importance of the beta coefficient obtained for the independent variable. The value of R2 expresses the prediction strength of the dependent variable using the independent variable, $\mathrm{R} 2$ value is $(52.8 \%)$ and this value also can be viewed as the variation percentage in the dependent variable that can be accounted for (i.e. explained by) the independent variable. 
As a result, the alternative hypothesis is accepted.

HO3.3: There is a significant impact of e-word of mouth on alternatives evaluation at $\alpha \leq 0.05$.

\begin{tabular}{|l|l|l|l|l|l|l|l|l|}
\hline $\begin{array}{l}\text { Independent } \\
\text { Variables }\end{array}$ & $\mathrm{r}$ & $\mathrm{R}^{2}$ & $\mathrm{f}$ & $\operatorname{Sig} \mathrm{f}$ & $\beta 0$ & $\beta$ Coefficient & $\mathrm{t}$ & Sig t \\
\hline E-Word of Mouth & 0.888 & 0.789 & 794.3 & 0.000 & 0.327 & 0.914 & 28.18 & 0.000 \\
& & & & & & & & \\
\hline
\end{tabular}

Table (14) Simple Linear Regression for Testing the HO3.3

As presented in table (14), the $f$ value (794.3) is significant because the related $p$ value $(0.000)$ is statistically significant $(<0.05)$. The beta coefficient reflects the impact value in the independent variable. The beta coefficient value is (0.914) and significantly contributes to the dependent variable as the probability of $\mathrm{t}$ statistics is $(0.000)<0.05$. The $\mathrm{t}$ statistics tests the linearity importance of the beta coefficient obtained for the independent variable.

The value of $\mathrm{R} 2$ expresses the prediction strength of the dependent variable using the independent variable, R2 value is $(78.9 \%)$ and this value also can be viewed as the variation percentage in the dependent variable that can be accounted for (i.e. explained by) the independent variable.

As a result, the alternative hypothesis is accepted.

HO3.4: There is a significant impact of e-word of mouth on e-purchasing at $\alpha \leq 0.05$.

\begin{tabular}{|l|l|l|l|l|l|l|l|l|}
\hline Independent Variables & $\mathrm{r}$ & $\mathrm{R}^{2}$ & $\mathrm{f}$ & $\operatorname{Sig} \mathrm{f}$ & $\beta 0$ & $\beta$ Coefficient & $\mathrm{t}$ & $\operatorname{Sig} \mathrm{t}$ \\
\hline E-Word of Mouth & 0.684 & 0.468 & 186.1 & 0.000 & 1.19 & 0.703 & 13.64 & 0.000 \\
& & & & & & & & \\
\hline
\end{tabular}

Table (15) Simple Linear Regression for Testing the HO3.4

As presented in table (15), the $f$ value (186.1) is significant because the related $p$ value $(0.000)$ is statistically significant $(<0.05)$. The beta coefficient reflects the impact value in the independent variable. The beta coefficient value is $(0.703)$ and significantly contributes to the dependent variable as the probability of $\mathrm{t}$ statistics is $(0.000)<0.05$. The $\mathrm{t}$ statistics tests the linearity importance of the beta coefficient obtained for the independent variable. The value of R2 expresses the prediction strength of the dependent variable using the independent variable, $\mathrm{R} 2$ value is $(46.8 \%)$ and this value also can be viewed as the variation percentage in the dependent variable that can be accounted for (i.e. explained by) the independent variable.

As a result, the alternative hypothesis is accepted.

HO3.5: There is a significant impact of e-word of mouth on post-purchasing evaluation at $\alpha \leq 0.05$.

\begin{tabular}{|l|l|l|l|l|l|l|l|l|}
\hline $\begin{array}{l}\text { Independent } \\
\text { Variables }\end{array}$ & $\mathrm{r}$ & $\mathrm{R}^{2}$ & $\mathrm{f}$ & $\mathrm{Sig} \mathrm{f}$ & $\beta 0$ & $\beta$ Coefficient & $\mathrm{t}$ & Sig t \\
\hline E-Word of Mouth & 0.314 & 0.098 & 23.1 & $0.000^{*}$ & 2.435 & 0.188 & 4.80 & 0.000 \\
& & & & & & & \\
\hline
\end{tabular}

Table (16) Simple Linear Regression for Testing the HO3.5

As presented in table (16), the $\mathrm{f}$ value (23.1) is significant because the related $\mathrm{p}$ value $(0.000)$ is statistically significant $(<0.05)$. The beta coefficient reflects the impact value in the independent variable. The beta coefficient value is (0.188) and significantly contributes to the dependent variable as the probability of $t$ statistics is $(0.000)<0.05$. The $t$ statistics tests the linearity importance of the beta coefficient obtained for the independent variable. The value of $\mathrm{R} 2$ expresses the prediction strength of the dependent variable using the independent variable, R2 value is $(9.8 \%)$ which is a low percentage, this 
value also can be viewed as the variation percentage in the dependent variable that can be accounted for (i.e. explained by) the independent variable.

As a result, the alternative hypothesis is accepted.

\subsection{Results and Conclusion}

The results presented by the statistical analyses above show that there are statistically significant relationships of social networking sites on e-purchasing process. The e-word of mouth and the epurchasing process both have strong positive linear relationships with e-purchasing process. The impact of e-reference groups is a little stronger than the impact of e-word of mouth on e-purchasing process.

The highest effect noticed for e-reference groups on the e-purchasing process is on the search information stage (second stage of the purchasing process). The impact of e-reference groups on need recognition, alternative evaluation and e-purchasing is strong as well but week on the post-purchasing evaluation.

The highest effect noticed for e-word of mouth on the e-purchasing process is on the alternatives evaluation stage (third stage of the purchasing process). The impact of e-word of mouth on information search is strong as well, the impact of e-word of mouth on need recognition and e-purchasing is moderate to strong, but week on the post-purchasing evaluation.

Based on the above, it could be concluded that social networking sites (represented by the e-word of mouth and e-reference groups) are playing vital role in allowing users to communicate, dialogue and exchange ideas through websites, apps, chatrooms, photo albums and others, resulting in a strong impact on e-purchasing process in the fashion sector in its five stages to the degree of its ability of changing consumers opinion completely and motivate them to get new fashion products.

In general, the results of this study came in a line with several previous studies (Shlash et al., 2011; Yang et al., 2007; Al-Jabari \& Nik, 2012) in terms of confirming the impact of social networking sites (ereference groups and e-word of mouth) on purchasing process. However, the results showed different levels of impact on each stage of the e-purchasing process, giving the fashion sector its own unique situation.

\subsection{Limitations, Recommendations and Future Research 6.1 Limitations of study}

The study faced a number of obstacles of which the majority was overcome during the implementation of this study. Mainly, the difficulty of limiting the number of people who make epurchasing in the fashion sector in Jordan which was overcome by arranging meeting with the main fashion e-stores in Jordan and ask for their help. Special arrangements were taken to guarantee the confidentiality of their data. Lack of official local statistics that presents the numbers of e-purchasing process in general and about the fashion sector in particular in Jordan was solved by turning to international sources for these statistics.

\subsection{Recommendations and Future Research}

Based on the results of the research, the main recommendations are that fashion e-stores should pay more attention to consumers' interactions especially in the stages of information search and alternatives evaluation. Providing enough information on the products and its alternatives will be very important in the e-purchasing process. Help the generation of positive comments, likes, shares, tags...etc. on social networking sites will positively and strongly impact the e-purchasing process, this can be done through enhancing the quality of products display (including information provided on each) and responding to the feedback customers share on their buying experience effectively.

As for future research, expanding the dimensions of social networking sites to include elements other than e-reference groups and e-word of mouth will be a good future research area. Also, examining the possible intervening impact of factors like culture norms and motivation for shopping on the original relationship between social networking sites and e-purchasing process will be important to understand. The impact of social networking sites on the traditional purchasing process in the fashion sector to compare results will be a thing to investigate. Testing the impact of social networking sites on other sectors to compare the results is also an interesting filed of investigation. Last but not east, repeating the 
same study in other markets (countries) to determine any possible differences between the Jordanian market and the regional and international ones.

\section{Acknowledgment}

The authors are grateful to the Applied Science Private University, Amman- Jordan, for the full financial support granted to this research project (DRGS-2018).

\section{References}

Abdulhameed Talaat, (2010), "The Purchasing decision to the final consumer", world of electronic creativity magazine.

Andersen, Margaret L. and Taylor, Howard F. (2010), Sociology: The Essentials, p.129, Cengage Learning.

Al-Dibese and Al-Tahat, (2013), " The role of social networking sites in shaping public opinion among Jordanian universities students", Humanities and Social Sciences Studies, Vol. 40, No. 1

Al- Jabari, M. A., Othman, S. N., Nik Mat, N. K. (2012), "Actual Online Shopping Behavior among Jordanian Customers", American Journal of Economics.

Alsomaydae and Yousef, (2007), "Consumer Behavior", , Dar Al-Manahij for Publishing and Distribution, Amman

AIMIA reports, (2013), "highlighting the behavior of today's customers and its impact on tomorrow's business, customer loyalty in the Middle East", available on

https://www.aimia.com/content/dam/aimiawebsite/CaseStudiesWhitepapersResearch/english/Aimia_CustomerL oyalty_MiddleEastArabic.pdf, accessed in 20 Dec. 2015.

Arab Social Media Report, (2015), Dubai School of Government Management, available on: http://www.arabsmis.ae/assets/frontend/images/ASMISArabicReport.pdf, accessed in 20 Dec. 2015.

Bakri, T. (2006), Marketing Modern Principles, Dar Alyzorie, Amman - Jordan.

Cheung, C.M.K. \& Lee, M.K.O. (2012), What drives consumers to spread electronic word of mouth in online consumer-opinion platforms. Decision Support Systems, 53(1)-218-225.

Creswell, J. W. (2005), "Educational research: Planning, conducting, and evaluating quantitative and qualitative research". Upper Saddle River, NJ: Pearson.

Curran, Fenton and Freedman, (2014), Misunderstanding the Internet, London: Routledge.

Daugherty, J., (2009), "Third-Person Effect and Social Networking: Implications for Online Marketing and Word-of- Mouth Communication", American Journal of Business", Vol.24, pp. 53 - 64.

Gremler, D.; Gwinner, K. \& Brown, S. (2001), Generating Positive WOM Communication Through Customer Employee Relationships, International Journal Pf Service Industry Management, 12 (1)- 41-5

Heriyati , P.and Siek T. P. (2011), Effects of word of mouth communication and perceived quality on decision making moderated by gender: Jakarta blackberry smartphone consumer's perspective, II Contemporary Management Research, vol. 7, no. 4, pp. 329-336.

Hisham T. and Abu Hamieda, (2007), " The impact of the expected risks during purchasing decision making processes to purchase household electrical appliances via the internet for the Jordanian consumer", Master Theses, Bani Sweif University, Egypt.

Internet live stats, (2016), "Internet users in Jordan", available on: http://www.internetlivestats.com/internetusers/jordan, accessed in 21st May. 2016.

Kotler, P., and Armstrong, G. (2012), Principles of Marketing, (14th ed.), Pearson Education, USA: Pearson Prentice Hall

Kotler, Ph, (2011), Marketing management, (14th ed.), New Jersey: Prentice Hall.

Luís, J. and Seabra, A., (2013),"Drivers of in-group and outof-group electronic word-of-mouth (eWOM)", European Journal of Marketing, Vol. 47 Iss. $_{\llcorner}$LP. 1067 - 1088.

Mauri, G. \& Minazzi, R. (2013), Web Reviews Influence on Expectation and Purchasing Intention of Hotel Potential Customers, International Journal of Hospitality Management, 31- 99-107.

Obidat, M. (2004), Consumer Behavior, Fourth edition, Dar Wael, Amman - Jordan.

Pookulangaran S. and Koesler K. (2011), "Cultural influence on consumers' usage of social networks and its' impact on online purchase intentions", Journal of Retailing and Consumer Services, Vol.18, PP. 348-354.

Befort: Payments Report, (2015), "highlight the volume of e-commerce", available on http://marketing.payfort.com/mailshots/url/sop15/SOP15_Final_Ar.pdf, accessed on $4^{\text {th }}$ April 2016 at 3:00 pm.

Shahana, S. and Dawn, L., (2007). "Why are you telling me this? An examination into negative consumer reviews on the Web". Journal of Interactive Marketing 21(4)-76.

Shlash Anbar I., Al-Houri Suleiman I., Al-Shoura Mohammad S. (2011), "The Impact Of E-Marketing on Achieving Competitive Advantage by The Jordanian Pharmaceutical Firms Dirasat", Administrative Sciences Journal, Vol. 38, No. 1. 
Sowaydan, (2011), " The Influence of the Word of mouth on the Purchasing Decision of the Consumer in terms of His Choice and Loyalty to the Trademark", Journal of Accounting, Management and Insurance, Cairo University, Issue 79, p. 8).

Tayeh Nidal, (2007), "The impact of Internet Advertising on Purchasing Decision Stages between the Palestinian University Youth in Gaza Strip", Master thesis, Islamic University, Gaza strip, Palestine.

Xie, H.; Miao, L.; Kuo, J. \& Lee, Y. (2011), Consumer Responses to Ambivalent Online Hotel Reviews: The Role of Perceived Source Credibility 90 And Pre-Decisional Disposition, International Journal of Hospitality Management, 30-178-183

Yang, T.A., Kim, D.J., Dhalwani, V. (2007), "Social Networking as a New Trend in E-Marketing", In CONFENIS, Vol. 2, PP. 847-856. 